American Journal of Laboratory Medicine
2020; 5(1): 1 -13
http://www.sciencepublishinggroup.com/j/ajlm
doi: $10.11648 /$ jajlm.20200501.11
ISSN: $2575-3878$ (Print); ISSN: $2575-386 \mathrm{X}$ (Online)

\title{
Influence of Climatic Factors on Aggression and Infectivity of Anopheles in the Districts the Indoor Residual Spray (IRS) in Northern Benin, West Africa
}

\author{
André Sominahouin 1, 2, ", Germain Gil Padonou ${ }^{1,3}$, Rodrigue Landéhou ${ }^{2}$, Albert Sourou Salako ${ }^{1}$, \\ Hermann Sagbohan ${ }^{1}$, Idelphonse Ahogni ${ }^{1}$, Sylvain Lokonon ${ }^{4}$, Razaki Osse ${ }^{1}$, Arsène Fassinou ${ }^{1}$, \\ Bénoît Assogba $^{5}$, Fiacre Agossa ${ }^{1}$, Fortuné Dagnon ${ }^{6}$, Christophe Houssou ${ }^{2}$, Martin Akogbéto ${ }^{1,3}$ \\ ${ }^{1}$ Cotonou Entomological Research Center (CREC), Cotonou, Benin \\ ${ }^{2}$ Department of Geography and Spatial Planning, University of Abomey, Calavi, Benin \\ ${ }^{3}$ Faculty of Science and Technology, University of Abomey, Calavi, Benin \\ ${ }^{4}$ Faculty of Economics and Management, University of Abomey, Calavi, Benin \\ ${ }^{5}$ Institute of Public Health Research, University of Abomey, Calavi, Benin \\ ${ }^{6}$ US President's Malaria Initiative, US Agency for International Development, Cotonou, Benin

\section{Email address:} \\ andrsominahouin@yahoo.fr(A. Sominahouin), pagergil@yahoo.fr(G. G. Padonou), landeourodrigue@yahoo.fr(R. Landéhou), \\ albertsourousalako@yahoo.fr(A. S. Salako),watson.sagbohan@yahoo.com(H. Sagbohan), ledr.id4ever@gmail.com(I. Ahogni), \\ sylokonon@yahoo.fr(S. Lokonon), Ossraz@yahoo.fr(R. Osse), arsènefassinou@yahoo.fr(A. Fassinou), \\ assobe80@gmail.com(B. Assogba),rofargossa@yahoo.fr(F. Agossa), fdagnon@usaid.gov(F. Dagnon), christpass@yahoo.fr(C. Houssou), \\ akogbetom@yahoo.fr(M. Akogbéto) \\ ${ }^{*}$ Corresponding author
}

\section{To cite this article:}

André Sominahouin, Germain Gil Padonou, Rodrigue Landéhou, Albert Sourou Salako, Hermann Sagbohan, Idelphonse Ahogni, Sylvain Lokonon, Razaki Osse, Arsène Fassinou, Bénoît Assogba, Fiacre Agossa, Fortuné Dagnon, Christophe Houssou, Martin Akogbéto. Influence of Climatic Factors on Aggression and Infectivity of Anopheles in the Districts the Indoor Residual Spray (IRS) in Northern Benin, West Africa. American Journal of Laboratory Medicine. Vol. 5, No. 1, 2020, pp. 1-13. doi: 10.11648/j.ajlm.20200501.11

Received: November 18, 2019; Accepted: December 18, 2019; Published: January 6, 2020

\begin{abstract}
Background: Climate variability influence the diversity and abundance of malaria vectors and thereby on malaria transmission dynamics. Examine its effect on Anopheles parameters involved in transmission may predict the potential malaria hotspot as a right target for its control intervention strategies. Here, we investigated the influence of meteorological parameters on the aggressiveness and infectivity of Anopheles in two health districts zones where IRS has been extended in Northern Benin. Mosquito collections were carried out using human landing catches to evaluate rates of aggression and infectivity in twelve villages. Concomitantly, meteorological data from synoptic stations of Benin and neighbouring countries were collected in 2016-2017. The spatial distribution of infective bites of An. gambiae is characterized by an intense aggression in the rural villages of the study area. Analysis of variances showed significant HBR difference according to the period but not according to the locality. However, the same analysis carried out with the infectivity rate shows no significant difference according to the period and the locality. In addition, the number of infective bites per man per month is higher in August and October, and the climatic parameters that have mainly favoured aggression are wind speed, humidity, sunshine and temperature. Indeed, the peak of wind speed is concentrated around $1.2 \mathrm{~km} / \mathrm{h}$ and in September $(5 \mathrm{~km} / \mathrm{h})$ whereas the aggressiveness score of Anopheles in the region is greater than 10 infective bites per man a year. Malaria transmission by Anopheles is influenced by climatic factors. The climate observed in the districts where IRS was extended in northern Benin has a real impact on Anopheles density and weakens current and future vector control strategies. This could lead to a series of modifications observed in anopheline populations just after IRS implementation ranging from a tendency to exophagy, from a decrease in the rate of blood-feeding to changes in the time, and change in aggressiveness. These phenomena most likely contribute to the sustainability of malaria transmission despite vector control measures.
\end{abstract}


Keywords: Infectivity, Aggression, Climate, Anopheles gambiae (s.l.), IRS, Benin

\section{Introduction}

Malaria is a climate sensitive disease and climatic data can be used to monitor and predict aspects of its spatial distribution [1, 2]: seasonality [3], year-to-year variability [4], and long term trends [5]. Moreover, climatic information's are increasingly used in the assessment of the real impact of malaria interventions $[6,7]$.

However, environment is a major determinant of malaria biodiversity and its transmission nature is highly depending on vector density, bioecology and blood feeding preferences [11] The survival of major malaria vectors and their adaptation to extreme weather conditions in the form of long and dreadful drought in some places of Africa, especially in semi-desert areas, remains not well elucidated $[12,13]$. In these areas, the water required for the development of Anopheles larvae is non-existent throughout the year (6-8 months) $[14,15]$ and the replenishment of larvae observed from the start of the rainy season in larval habitats of Anopheles remains poorly documented [16]. It should be noted that the climatic factors were also favorable for larvae and adult mosquitos' development [17]. Fully sunny and quite warm temples were rather favorable to the aggressiveness and infectivity of mosquitoes from temporary submerging wetlands [18]. The observations made in the field are formal: the number and aggressiveness of mosquitoes increase in areas of very short duration and high malaria transmission (www.lerepublicain.net). In the northern part of Benin where the dry season lasts about a semester, many cases malaria are diagnosed during the dry season at consultations in health facilities [19]. Although these unexpected cases were related to relapses or cases of imported malaria case, the possibility of recent infections is not to be discounted given the magnitude of the incidence.

The aim of this study is to investigate the impact of different climatic parameters on the temporal dynamics of aggressiveness and infectivity among Anopheles in northern Benin. This research will enable the Ministries of Health and Environment to better refine their strategies in order to protect populations from mosquito bites.

\section{Materials and Methods}

\subsection{Study Sites}

The study was carried out in two health zones composed of six districts in northen Benin: Kandi-Gogounou-Ségbana health zone in Alibori province and Djougou-Copargo-Ouaké health zone in Donga province (Figure 1). These sectors are selected by the National Malaria Control Program (NMCP) based on epidemiological, ecological, environmental and socio-economic criteria to extend IRS operations from 2017. The region's crop diversity includes yams, sorghum, maize, millet, cowpeas, cassava, beans and groundnuts for foodproducing crops and cotton, shea and cashew for cash crops. Collecting and processing cashew and shea are the main sources of income for the populations. Kandi-GogounouSégbana health districts zone is about $12,943 \mathrm{~km}^{2}$, the cumulative incidence of malaria cases is $14.1 \%$ across all ages and the mortality due to malaria is $6.2 \%$ for children aged 0-4 years in 2015 [20] (MS, 2016). Djougou-CopargoOuaké health district zone is about $5,465 \mathrm{~km}^{2}$ with 397,942 inhabitants in 2012, the cumulative incidence of malaria cases is $28 \%$ and the mortality due to malaria is $37,5 \%$ in 2015 [21]. Long- lasting insecticidal nets (LLINs) are the main tool for malaria prevention in these districts.

\subsection{Sampling Methods of and Mosquito Collections}

\subsubsection{Study of Population Dynamics of Vectors and Malaria Transmission}

From May 2016 to February 2017, a longitudinal study was conducted to assess the spatio-temporal dynamics of Anopheles mosquitoes and malaria transmission in the northern part of Benin Republic. For this study, Anopheles mosquito collections were conducted in twelve (12) villages including six urban villages and six peripheral outlying villages in both health zones. The localities include: Kossarou, Sonsoro, Bantasoue, Gounarou, Ségbana center, Liboussou, Bariénou, Zountori, Parakouna, Kataban, Aboulaoudé and Kondé. In Kandi, Gogounou, Djougou and Copargo districts, mosquito collections were carried out using simultaneously both human landing catches (HLC) and pyrethrum spray collection (PSC). In Ségbana and Ouaké districts, mosquito collections were exclusively carried out using PSC. Mosquitoes were collected once a week for 7 months from 24 houses by PSC from 06.00 A. M to 09.30 A. M.

\subsubsection{Human Landing Catches}

This method contributed to the evaluation of the interactions between the vector and the human host. As the number of vectors which bite humans per unit of time is an important parameter in estimating the level of malaria transmission, it revealed which Anopheles bite humans, which species are vectors of malaria, how many times a person is bitten by a vector per unit of time, and whether the vectors bite inside or outside the dwellings. As part of this study, HLC were carried out from May 2016 to February 2017. The estimation of malaria vector transmission indicators is devoted to the most important entomological indices in the characterization of malaria transmission by a vector population. 


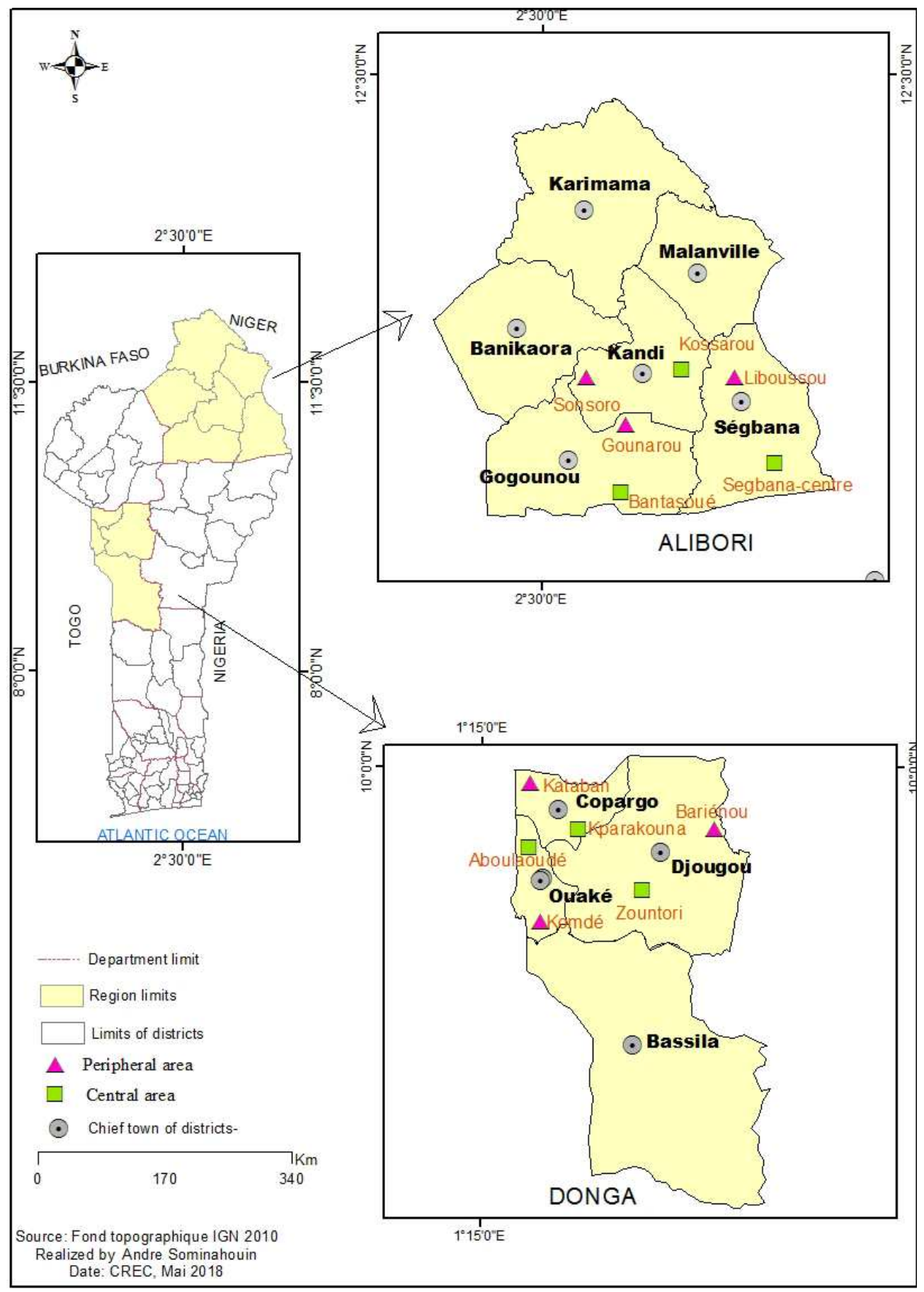

Figure 1. Map of Benin showing the study area.

\subsubsection{Mosquito Screening for Plasmodium Falciparum Sporozoite for Sporozoitic Index (SI) Estimation}

The head and thorax of each mosquito was carefully separated from the abdomen and tested for the presence of P.falciparum circumsporozoite protein (CS) as described by [22]. Briefly, mosquitoes were ground individually in $50 \mathrm{ml}$ boiled casein containing Nonidet 40 and final volume brought to $250 \mathrm{ml}$ with blocking buffer; $50 \mathrm{ml}$ of the mixture was used in ELISA tests. Absorbance was measured with ELISA reader (Titertek) at $414 \mathrm{~nm}$. Samples were considered positive (infected) when absorbance values exceeded the mean plus 3 standard deviations of the mean absorbance of eight negative controls [23].

The rate of infection is the proportion of sporozoitecarrying mosquitoes in their salivary glands: Sporozoitic Index $(\mathrm{SI})=$ number of mosquitoes positive $\div$ total number of mosquitoes analyzed [24]. 


\subsection{Climatic Data Collection and Analysis}

A Garmin Etrex 10 branded GPS was used to record the geographical coordinates of the twelve survey locations. A laptop with Windows operating system, ArcGIS 10.3 software and the DNR garmin extension were used for the mapping. Climate data include temperature, rainfall, wind speed, etc were collected from CRU database (Climate Research Unit, 10'x10', 1951-1990) and Météo-Bénin database related to the period 2016 to February 2017. This is the monthly data of Météo-Bénin regarding 3 synoptic stations of North-Benin namely stations of Kandi, Natitingou and Parakou, and the stations of Niamey in Niger, Ouagadougou in Burkina-Faso, Kara in Togo and Ilorin in Nigeria.

In order to have the climatic data in all points of the two health zones, spatial interpolations of the temperature, the rainfall, the wind speed, the vapor pressure, etc were carried out. Through these interpolations, zonal statistics were recorded for each of the twelve study localities. The extension " plot is a maneuver " for successful batch sharing of different climatic and entomological variables in geographical and temporal settings. It is used to explore the relationship between three variables on a block to subdivide, consider the combinations of $\mathrm{X}$ and $\mathrm{Y}$ that produce the corresponding values for the predictors on the $\mathrm{X}$ and $\mathrm{Y}$ axes while the outlines of lines and color bands of values for the Z-factor (involvement or reaction). Some analyzes including correlation, regression, Student Newman Keulset, and Principal Component Multivariate Analysis (PCA) were carried out with Minitab 15 and SAS software.

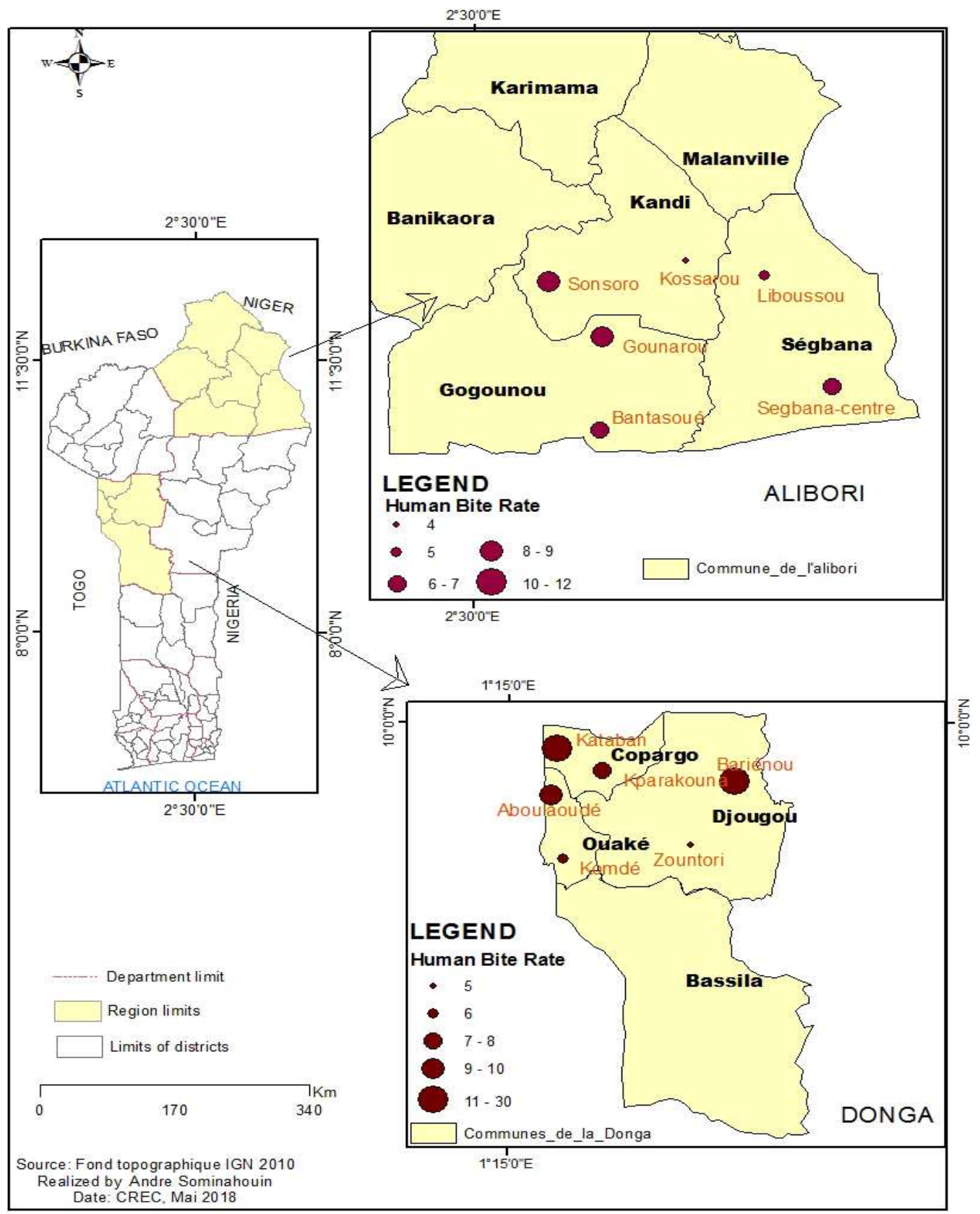

Figure 2. Spatial distribution of average cumulative rate of aggression in districts of Kandi, Gogounou, Djougou and Copargo. 


\section{Results}

Spatial distribution of Anopheles aggressiveness in the study area

Figure 2 shows that the spatial distribution of the Anopheles sl aggression rate varies moderately from 4 to 12 in the communes of the KGS health zone and from 5 to 30 bites per man per month in the communes of the COD health zone according to the urbanization situation and the type of village of residence. In fact, there are 175 infective bites per person per year ( $\mathrm{p} / \mathrm{h} / \mathrm{yr})$ in the rainy season and in the dry season. Malaria transmission has been almost permanent.

The spatial distribution of infective bites of An. gambiae s.l. (Figure 2) is characterized by an intense aggressiveness in the rural villages (Sonsoro, Gounarou, Liboussou, Barienou, Kataban, Aboulaoudè) of the study area. Such a distribution makes it possible to suspect that, after being fully blood-fed, a multitude of female Anopheles leave in search of rest sites to digest their meal. Two days later, these vectors easily find the natural reservoirs of stagnant water not heavily polluted (preferably sunny and with vegetation) and of different sizes such as ponds, swamps, puddles and leaves that are potential areas for egg-laying and larval breeding.

Variation of infected mosquitoes according to degree of urbanization and season A total of 3788 mosquitoes were tested in the laboratory and 305 mosquitoes (8.05\%) are infected with 50 identified during the dry season (May 2016January, February 2017) and 255 during the rainy season (June, July, August and October 2017). However, depending on the degree of urbanization, $82 \%$ of the malaria vector mosquitoes were in the rural areas and $18 \%$ in the urban areas (Table 1).

Table 1. Spatio-temporal variation of the infectivity of An. Gambiae s.l with Plasmodium falciparum.

\begin{tabular}{|c|c|c|c|c|c|c|}
\hline Districts & & $\begin{array}{l}\text { Mean } \\
\text { (DS) } \\
\end{array}$ & $\begin{array}{l}\text { Mean } \\
\text { (RS) } \\
\end{array}$ & Mean (7 months) & $95 \% \mathrm{CI}$ & P-value \\
\hline \multirow{3}{*}{ Total (Alibori Region) } & Thorax & 204 & 1310 & 1514 & \multirow{15}{*}[0.1-4.24]{} & \multirow{15}{*}{0.086} \\
\hline & Thorax + & 13 & 106 & 119 & & \\
\hline & SI & $6.37 \mathrm{a}$ & $8.09 \mathrm{a}$ & 7.86 & & \\
\hline \multirow{3}{*}{ Total (Donga Region) } & Thorax & 425 & 1849 & 2274 & & \\
\hline & Thorax + & 37 & 149 & 186 & & \\
\hline & SI & $8.71 \mathrm{a}$ & $8.06 \mathrm{a}$ & 8.18 & & \\
\hline \multirow{3}{*}{ Total (Rural areas) } & Thorax & 510 & 2601 & 3111 & & \\
\hline & Thorax + & 43 & 219 & 262 & & \\
\hline & SI & $8.43 \mathrm{a}$ & $8.42 \mathrm{a}$ & 8.42 & & \\
\hline \multirow{3}{*}{ Total (Urban areas) } & Thorax & 119 & 558 & 677 & & \\
\hline & Thorax + & 7 & 36 & 43 & & \\
\hline & SI & $5.88 \mathrm{a}$ & $6.45 \mathrm{a}$ & 6.35 & & \\
\hline \multirow{3}{*}{ Grand Total } & Thorax & 629 & 3159 & 3788 & & \\
\hline & Thorax + & 50 & 255 & 305 & & \\
\hline & SI & $7.95 \mathrm{a}$ & $8.07 \mathrm{a}$ & 8.05 & & \\
\hline
\end{tabular}

Variation of human biting and infectivity rates according to localities and periods

Table 2 shows the results of variance analyses carried out on localities and the period according to the different numbers of infective bites per man and per month (HBR) as well as the infectivity rate (IS). It appears from this table that there was significant difference of HBR ( $p>0.001)$ according to the period but no significant difference was observed per location. Similarly, the analysis of variances of the infectivity rates does not show any significant difference according to the period and the locality. These analyses show that HBR varies from one month to another. The mean sporozoite rates for An. gambiae s.l. over the study period are estimated at $4.54 \%$.

Table 2. Analysis Of Variance.

\begin{tabular}{lllll}
\hline \multirow{2}{*}{ Variances } & Degree of Freedom & \multicolumn{2}{l}{ F value Entomogical parameters } \\
\cline { 3 - 4 } & & & IS & HBR \\
\hline Months & 6 & F-statistic & $1.09 \mathrm{~ns}$ & $16.55^{* * *}$ \\
Localities & 3 & F-statistic & $1.04 \mathrm{~ns}$ & $0.61 \mathrm{~ns}$ \\
\hline
\end{tabular}

Table 3. Content (average \pm standard error) obtained in the different months.

\begin{tabular}{lll}
\hline \multirow{2}{*}{ Months } & Entomological indicators \\
\cline { 2 - 3 } & Sporozoitic Index (SI) & Human Bite Rate (HBR) \\
\hline May & $0.05 \pm 0.04$ & $0.81 \pm 1.41 \mathrm{c}$ \\
June & $0.02 \pm 0.01$ & $3.86 \pm 1.27 \mathrm{c}$ \\
July & $0.04 \pm 0.01$ & $7.75 \pm 1.32 \mathrm{~b}$ \\
August & $0.07 \pm 0.02$ & $11.86 \pm 1.87 \mathrm{a}$ \\
October & $0.14 \pm 0.02$ & $0.25 \pm 0.40 \mathrm{a}$ \\
January & $0.27 \pm 0.21$ & $1.53 \pm 0.46 \mathrm{c}$ \\
February & $0.47 \pm 0.02$ & $2.15 \pm 1.07 \mathrm{c}$ \\
\hline
\end{tabular}


Student Newman Keuls (SNK) tests showed higher monthly HBR in July and August whereas lower rate was recorded in May, June, January and February. The correlation and regression analyzes identified climatic factors which led to the increase in HBR during August and October (Table 3).

The regression equation for Anopheles s.l aggressiveness as a function of climatic parameters is written as follows:

$\mathrm{HBR}=44.0+0.161$ humidity +3.65 wind -0.254

temperature - 0.173 FTE -0.119 rain -0.126 sunshine

Climatic parameters which have mainly favored aggression are wind speed, humidity, sunshine and temperature.
Impact of wind speed on aggression (expresses wind speed in $\mathrm{km} / \mathrm{h}$ )

The profiles obtained show the peak which is concentrated around $1.4 \mathrm{~km} / \mathrm{h}$ (wind) in july and August $(4 \mathrm{~km} / \mathrm{h})$. The aggression score of Anopheles s.l in the region is greater than 12 bites per man per night in Djougou and 15 in Copargo (Figures 3; 4; 5; and 6).

However, for the profiles that respectively match with the wind speed in Kandi and Gogounou, the peak was around 1.2 $\mathrm{km} / \mathrm{h}$ (wind) in October and in September $(5 \mathrm{~km} / \mathrm{h})$. The aggression score of Anopheles in the region is greater than 10 bites per man per night.

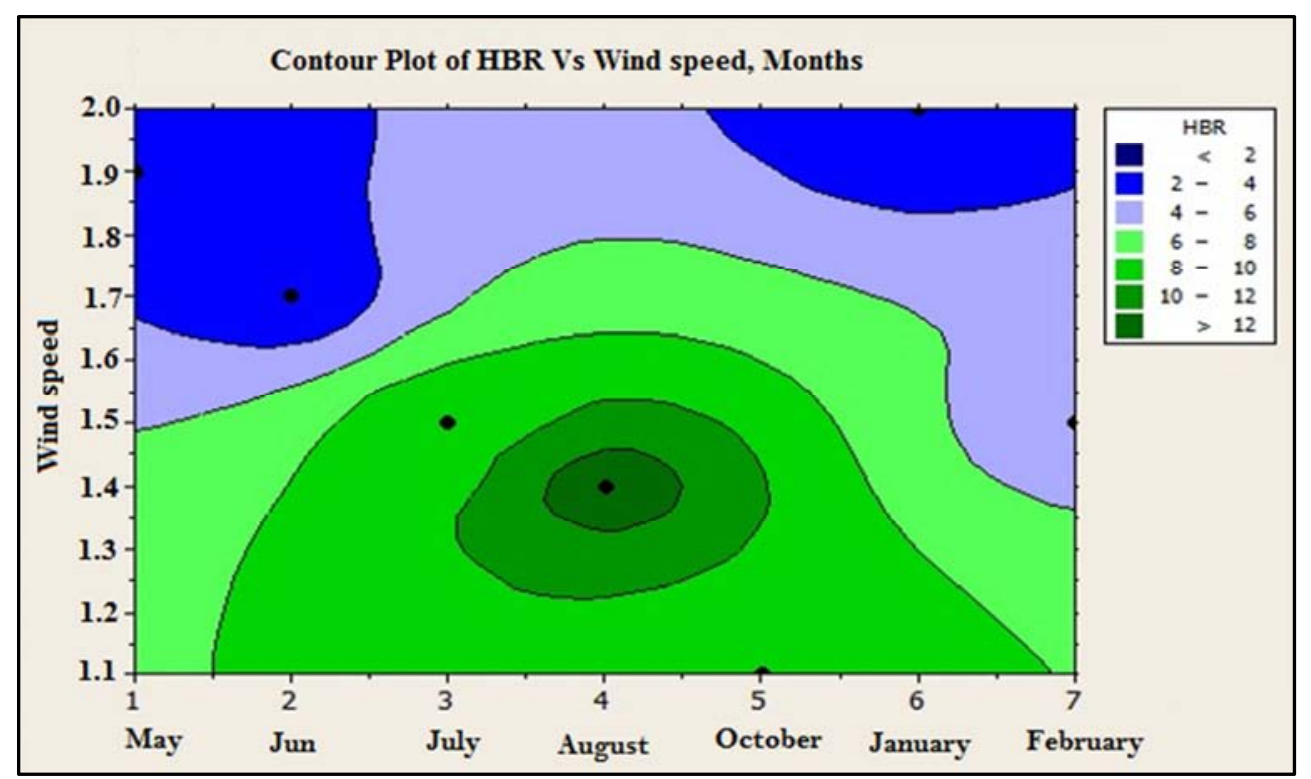

Figure 3. Multivariate map of the influence of wind speed according to HBR-months in Djougou.

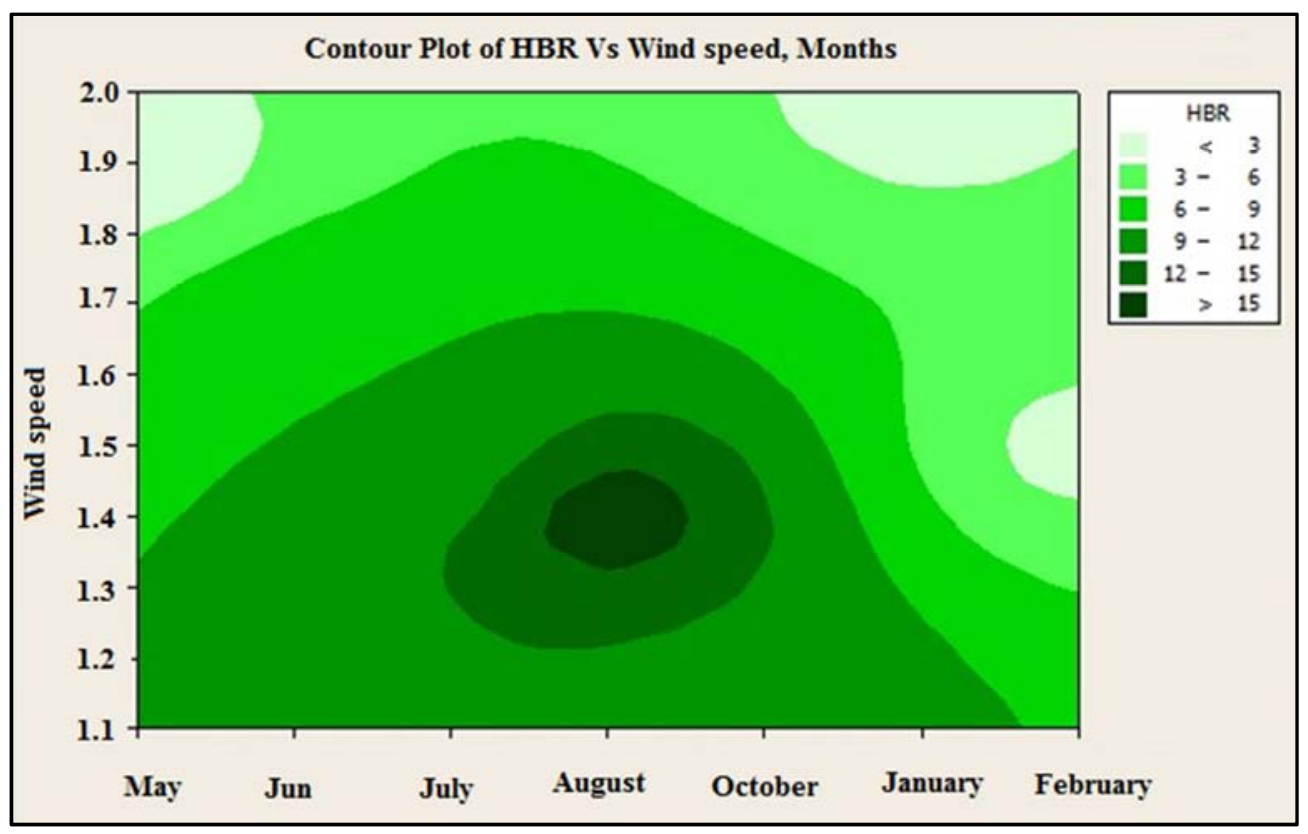

Figure 4. Multivariate chart of the influence of wind speed according to HBR-months in Copargo. 


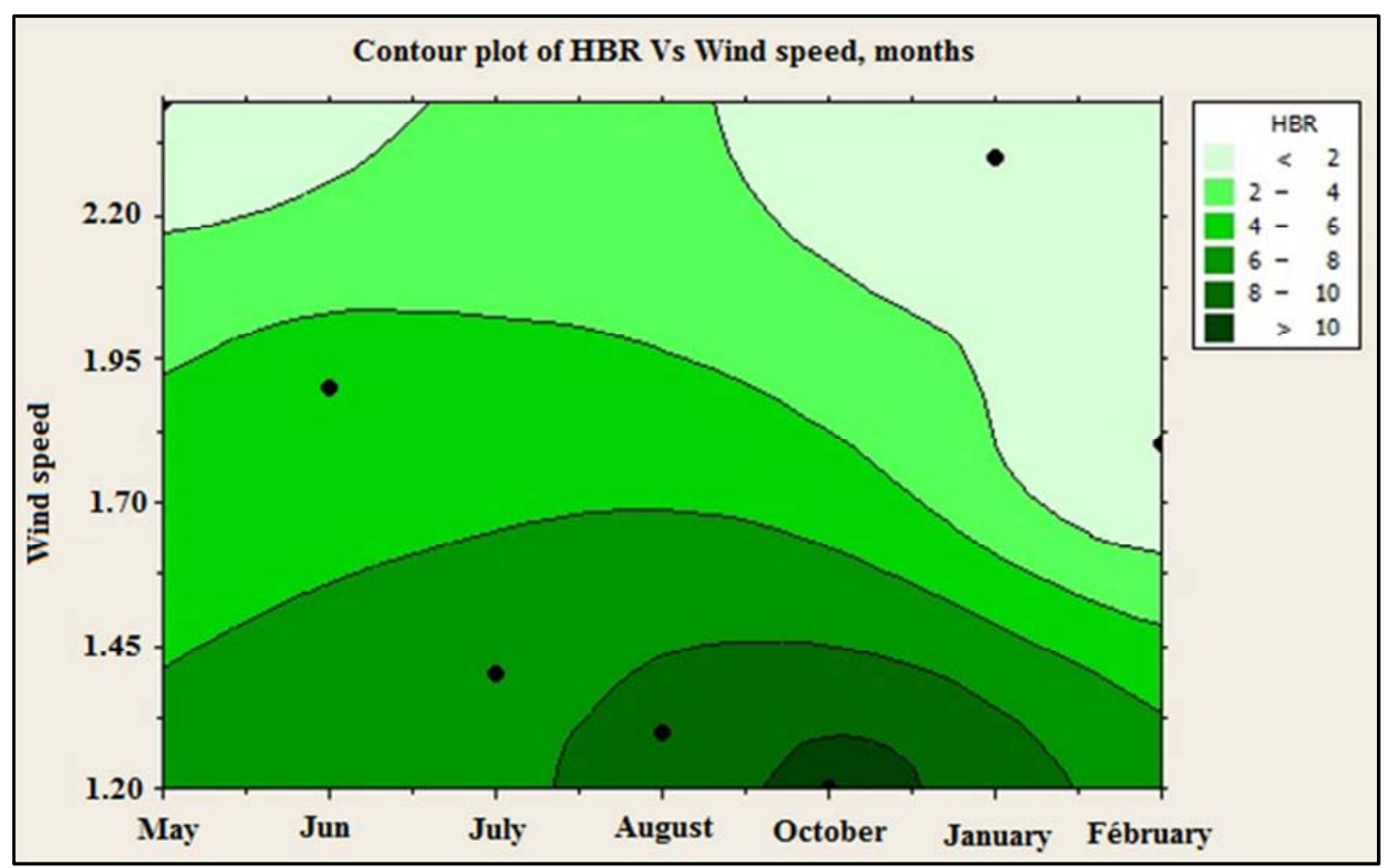

Figure 5. Multivariate map of the influence of wind according to HBR-month in Kandi.

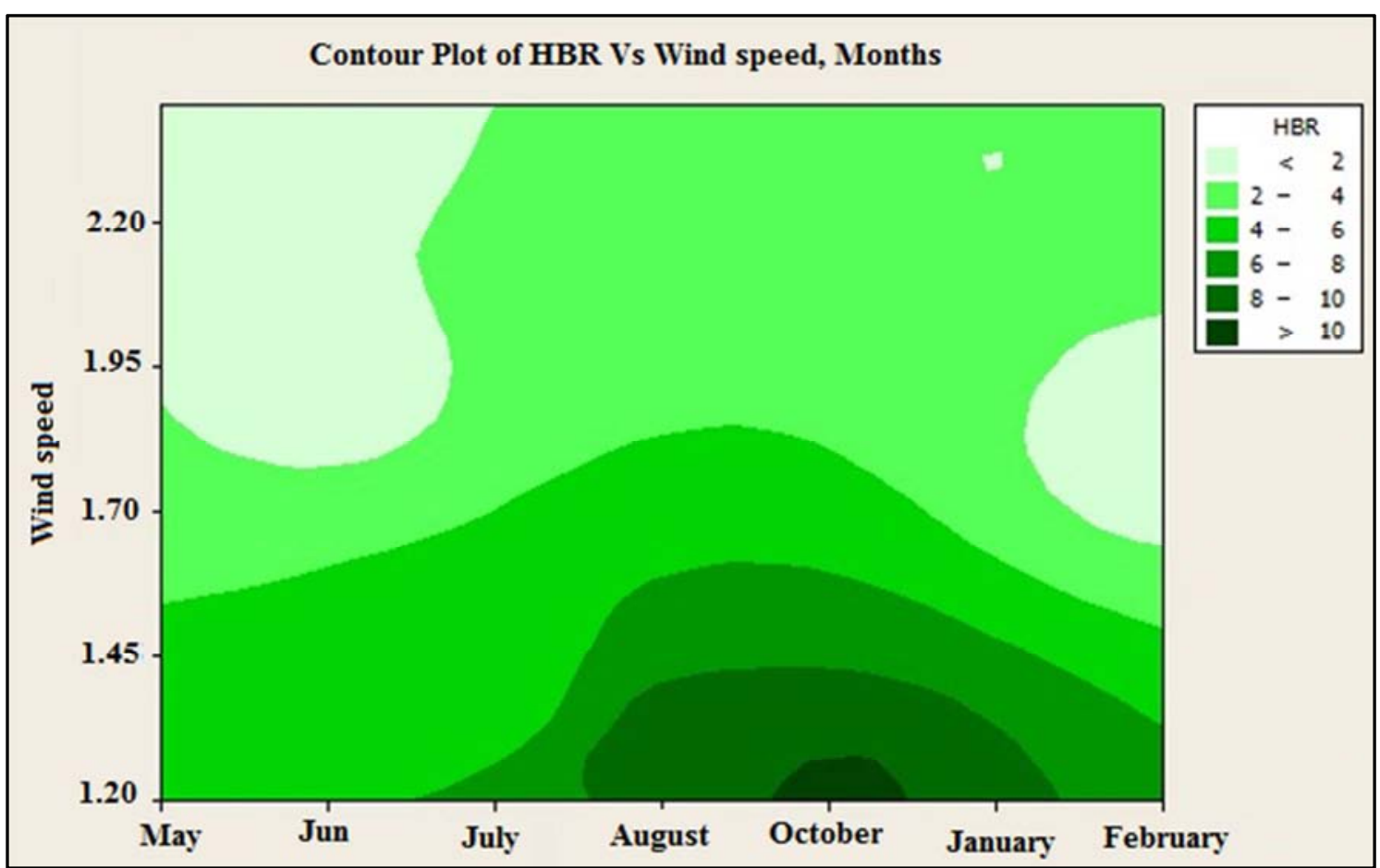

Figure 6. Multivariate map of the influence of wind according to HBR-month in Gogounou.

Impact of sunshine on aggression

Figures 7 and 8 showed two different profiles. These two profiles correspond respectively to the sunshine in Kandi and Gogounou. The aggression peaks when sunshine approaches
130 hours per month and extends between August and October. The aggression score of Anopheles in the area is greater than 10 bites per man per month (figure 9). 


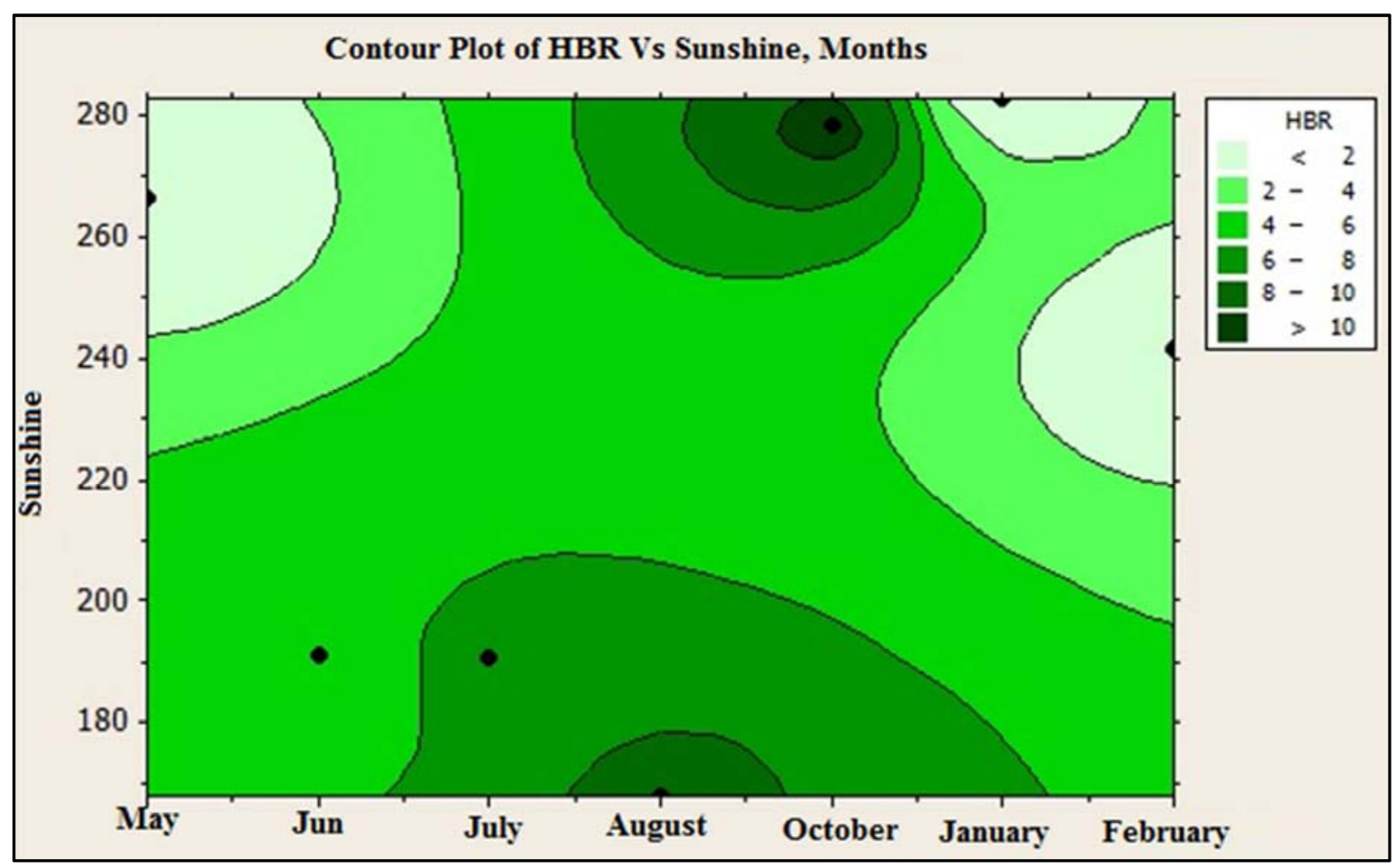

Figure 7. Multivariate map of the influence of sunshine according to HBR-month in Kandi.

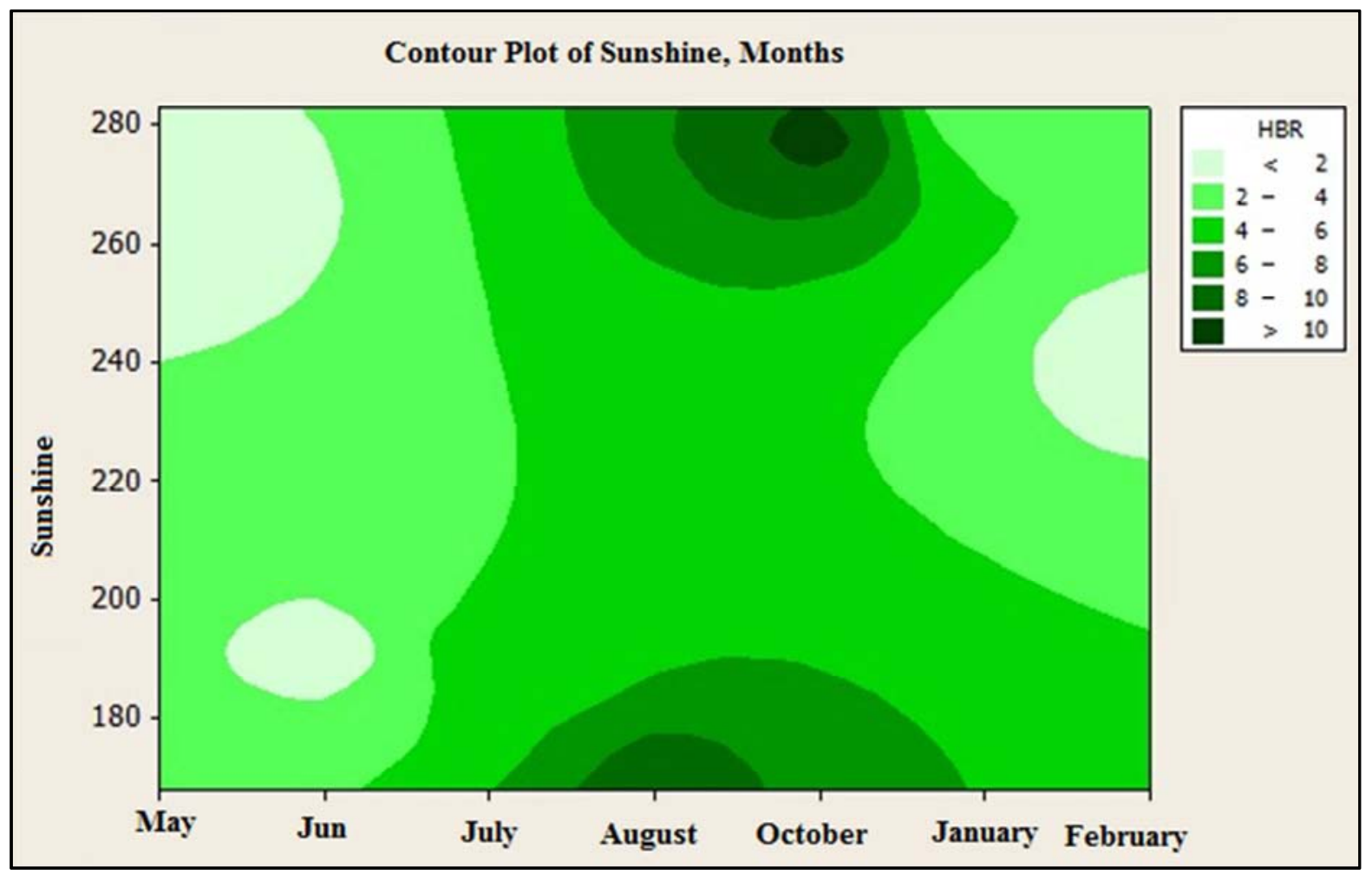

Figure 8. Multivariate map of the influence of sunshine according to HBR-month in Gogounou. 


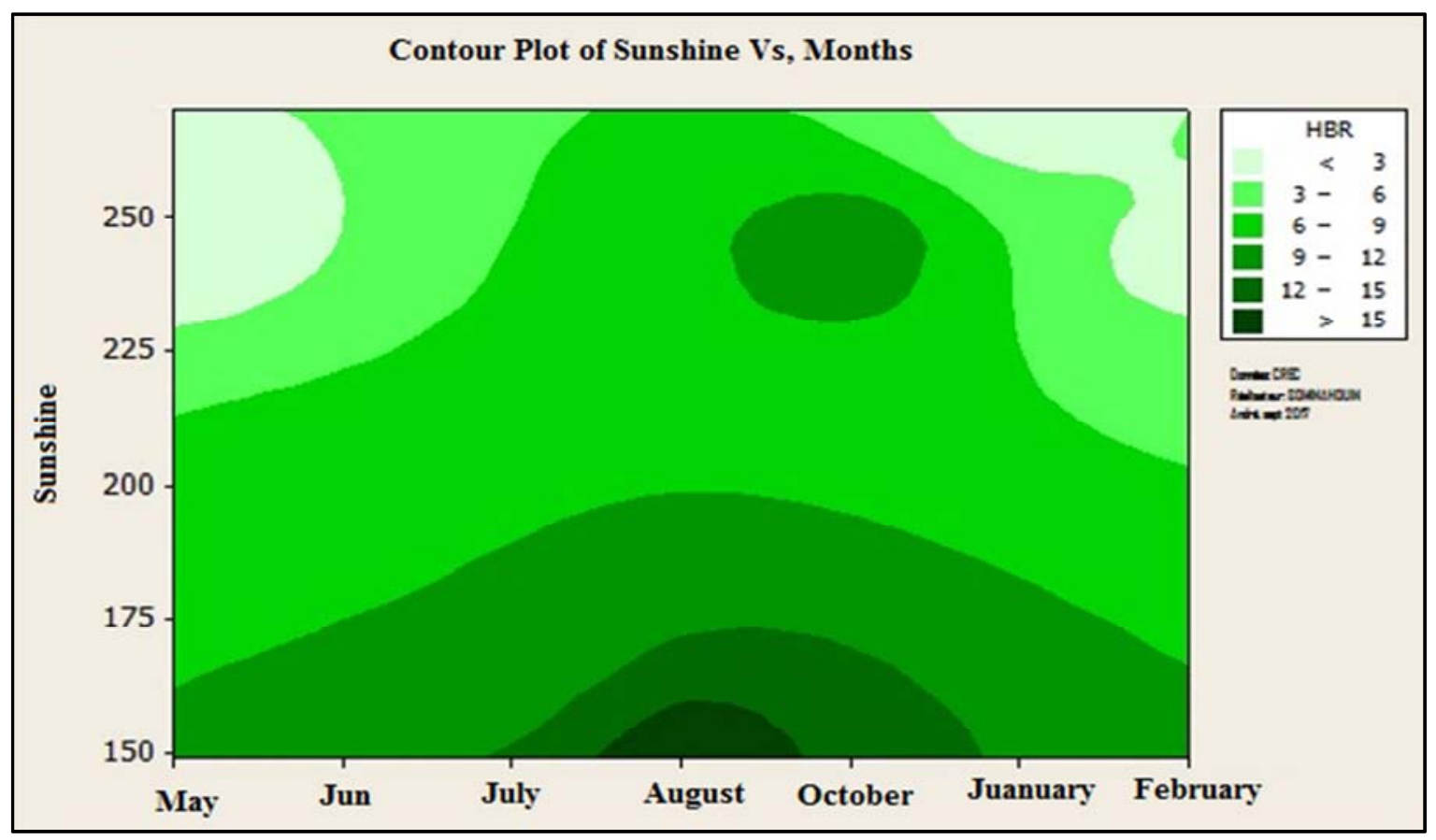

Figure 9. Multivariate map of the influence of sunshine according to HBR-month in Djougou.

Results of PCA rotation graphs

Rain and humidity constitute the climatic factors which greatly contribute to the intense Anopheles activity from June to August. Similarly, temperature, sunshine and evapotranspiration are climatic parameters which positively contributed to the existence of aggression in February and May. However in January, the aggressiveness of Anopheles is due to the wind. There is a contradiction between the climatic combination (rain, humidity) on the one hand and combination (sunshine, evaporation, wind) on the other hand. At month level, there is a month convergence of January, February, May and October with wind, sunshine, temperature and evaporation (ETP) (Figures 10, 11, 12).

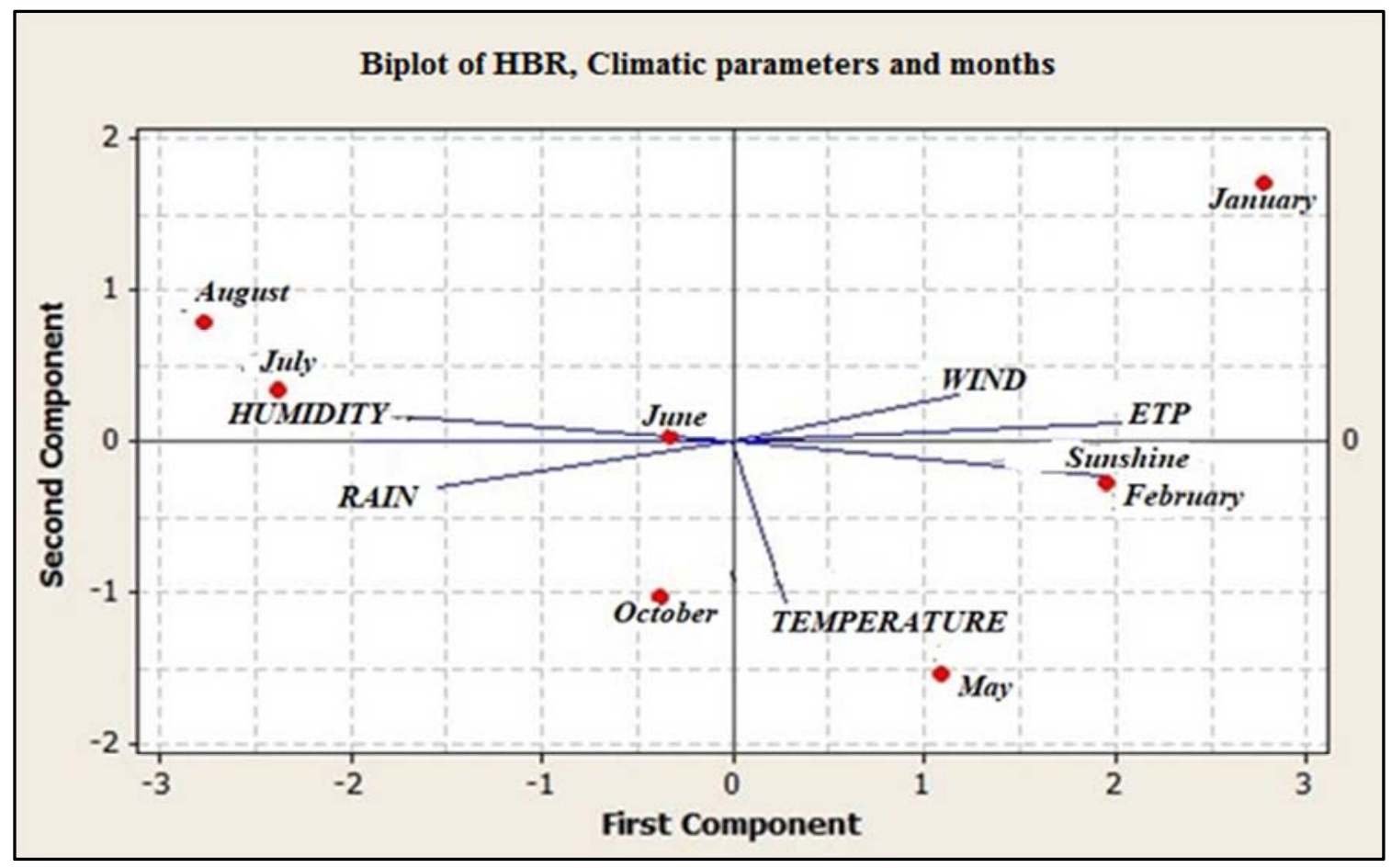

Figure 10. Graph showing ACP results on HBR according to climatic parameters in Copargo. 


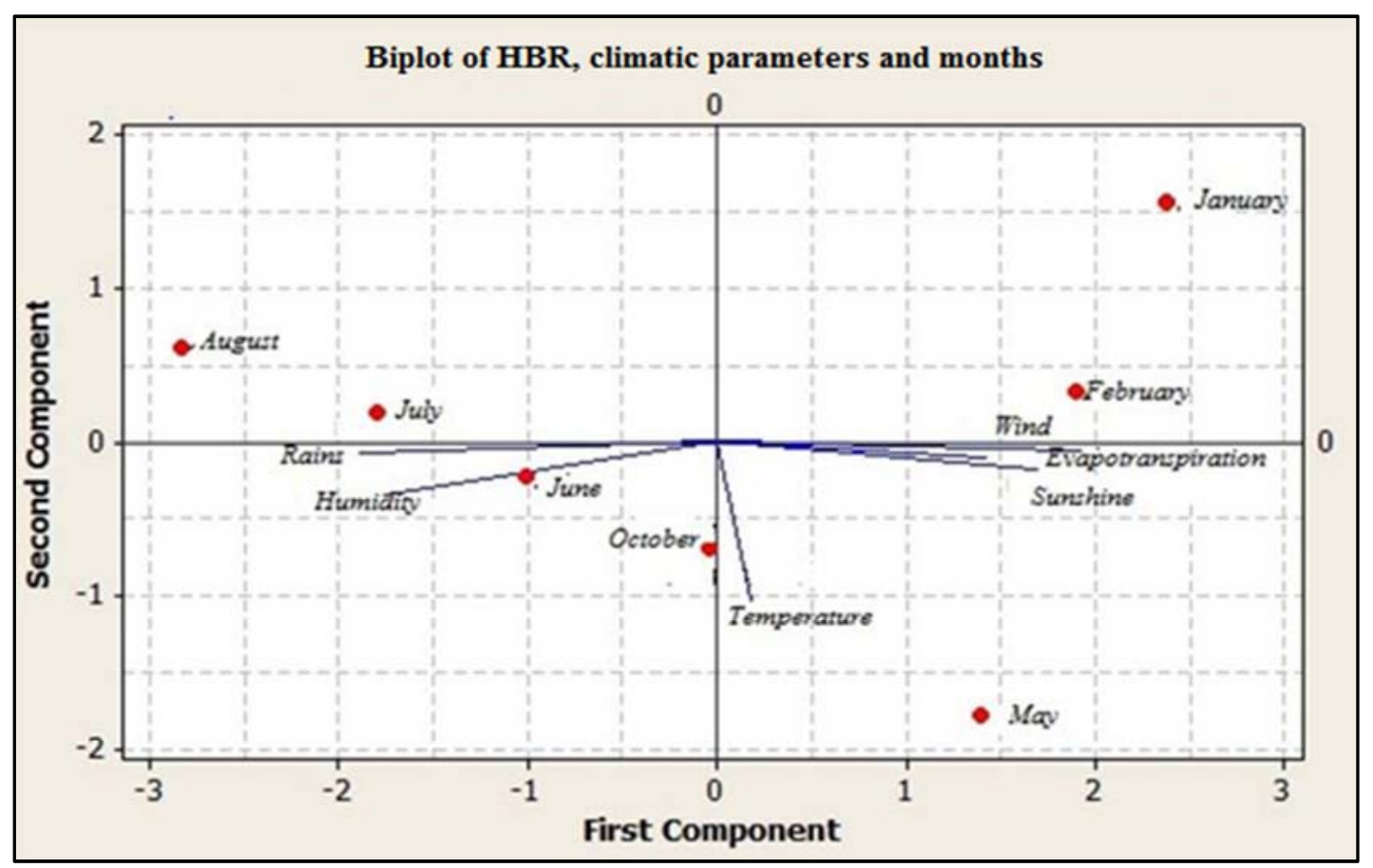

Figure 11. Graph showing ACP results on HBR according to climatic parameters in Gogounou.

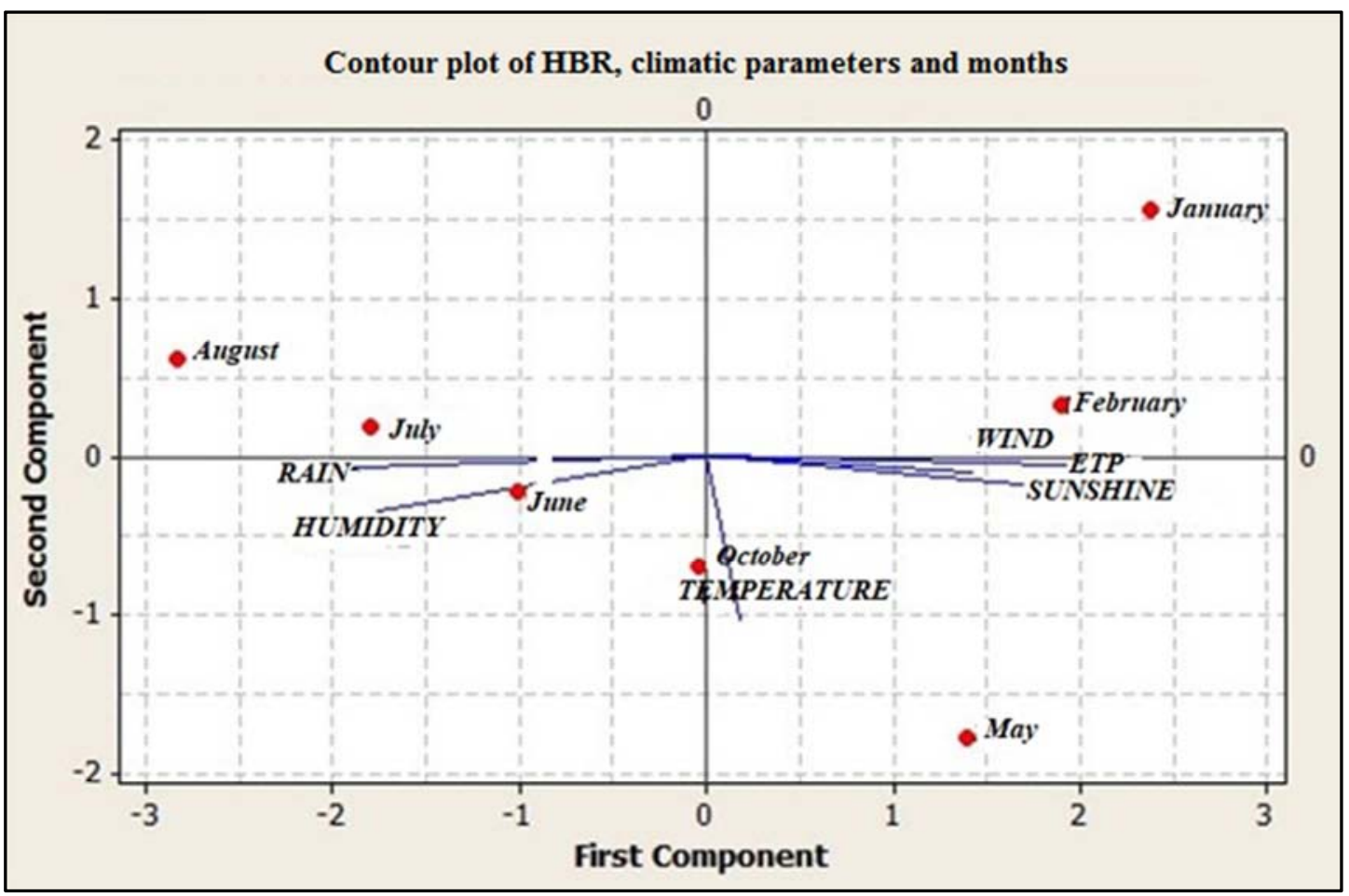

Figure 12. Graph showing PCA results on HBR as a function of climatic parameters in Kandi.

Factors involved in the aggressiveness of anopheles in the commune of Djougou

The hierarchical ascending classification (HAC) analysis based on 5 parameters which determine the occurrence of transmission more clearly allows distinguishing four categories of factors with a clear separation between sets (Figure 13). The classification represented by the dendrograms shows four categories of aggressiveness parameters. The first includes the ETP and the sunshine. The second includes temperatures, representing the class of parameters which are favorable to the aggressiveness of Anopheles in the district. The third is the category of humidity, which actually is the class of amplifier parameters and it determines the number of bites received by a person in the area.

Finally, the fourth which includes rains is the class of factors for recovery of mosquito bites. 


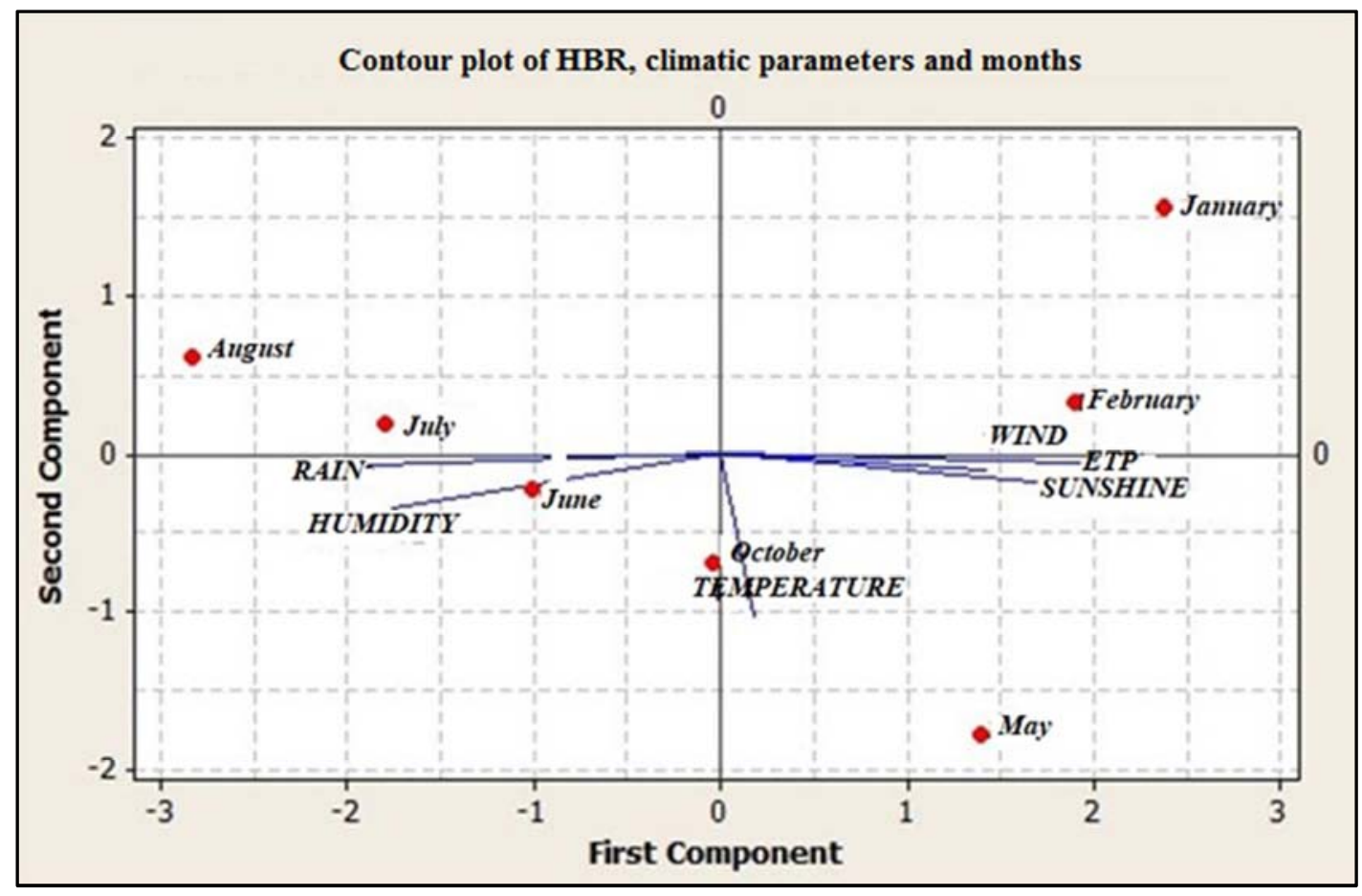

Figure 13. Graph showing PCA results on $H B R$ as a function of climatic parameters in Kandi.

\section{Discussion}

The study of the influence of climatic parameters on the aggressiveness and infectivity of Anopheles s.l in Northern Benin is essential not only to understand the effect of climate on the dynamics of transmission but also to establish an effective and targeted control of these vectors taking into account climate variability. The study was carried out in two health zones composed of six communes of North-Benin: the health zone Kandi-Gogounou-Ségbana in the department of Alibori and the health zone Djougou-Copargo-Ouaké in the department of Donga in the aim of identifying climate variables favorable to the strong aggressiveness and infectivity of Anopheles s.l in the said zone. These data will be used to evaluate the effectiveness of the strategy for the indoor sprinkling of large scale remnant insecticides, for the reduction of malaria transmission in the beneficiary communes. Longitudinal entomological and climatic monitoring, carried out for seven months in these villages, allowed us to take into account the main climate parameters that are implicated in the transmission of malaria in North Benin. Two members of the An. gambiae complex were found in the study area. This is An. gambiae s.s. and An. funestus. On the other hand, the anopheles density increases considerably during the rainy months and this increase is related to the rainfall. This result asserts the accuracy of the work of Klinkenberg et al. (2008) [25] in Ghana and Okono et al. (2015) [26] in Cameroon where these authors showed that the anopheles density is a function of the period. Each peak or decrease in rainfall was responsible for an increase or decrease in the climate parameters recorded in the area.

On the other hand, the average rate of aggressiveness of
Anopheles s.l ranges from 4 to 12 in the communes of the health zone KGS and from 5 to 30 stings per man per month in the communes of the health zone DCO depending on the urbanisation situation and the type of village of residence. This result confirms the work of Téné in 2007 in the cliff of Mbô which shows that the mean aggressiveness was higher in the plain $(9.34 \mathrm{~b} / \mathrm{h} / \mathrm{n})$ than on the plateau $(5.29 \mathrm{~b} / \mathrm{h} / \mathrm{n})$, but the entomological inoculation rate did not show such a large difference; $51.84 \mathrm{ib} / \mathrm{h} / \mathrm{y}$ with seasonal transmission and 47.68 $\mathrm{ib} / \mathrm{h} / \mathrm{y}$ with perennial transmission, respectively. This could be explained by the drop in temperature at altitude which extended the duration of the gonotrophic cycle by one day for the 2 species. According to them, despite the lower anophelian aggressiveness at altitude, the sporozoitic index is higher at Dschang (2.47\%) than at Santchou (1.52\%). This higher plasmodial prevalence in the vector can be explained by the migration of populations from the lower, more malarious lowlands to the uplands.

Our work is in line with that of Rhodain and Perez [27] in 1985 and Tchuinkam et al., 2007 [28] which shows that at altitude, the drop in temperature and hygrometry are at the origin of the lengthening of the gonotrophic cycle.

Climatic parameters which have mainly favored aggression are wind speed, humidity, sunshine and temperature. These works are similar of mosquitosquad [29] in 2018 which those the recipe for mosquito activity is heat + rainfall $=$ humidity, and this, combined with stagnant water means the perfect soupy combination for mosquito madness The temperature and activity of mosquitoes go hand in hand with insects that thrive in humid and relatively warm environments, working best at $20^{\circ} \mathrm{C}\left(80^{\circ} \mathrm{F}\right)$. Once the temperature has decreased to about $20^{\circ} \mathrm{C}\left(60^{\circ} \mathrm{F}\right)$, they 
become lethargic and, below $50^{\circ} \mathrm{C}\left(80^{\circ} \mathrm{F}\right)$, it is difficult to operate. If it's too hot and too dry, mosquitoes will not be as active and will not feed as usual. But once the temperature drops a little and is within the tolerable range for mosquitoes, they get more hungry and therefore bite more.

On the other hand, the anopheelian density and their infectivity increase considerably in the temporal and geographical context and this increase is related to the wind speed, the rainfall. This result confirms the work of Klinkenberg et al. (2008) [25] in Ghana and Okono et al. (2015) [26] in Cameroon where these authors showed that the anophelian density is seasonal. Each peak or decrease in rainfall was responsible for an increase or decrease in the population of An. gambiae s.l.

Student Newman Keuls (SNK) tests showed higher monthly HBR in July and August whereas lower rate was recorded in May, June, January and February. De plus, the correlation and regression analyzes identified climatic factors which led to the increase in HBR during August and October. This duration of strong anopheles aggressiveness is lower than those obtained in the municipality of Corpargo in northeastern Benin (Yadouléton et al., 2018) [30]. However, the months of May, July and September are the months when populations receive more bites. In addition, research on $P$. falciparum infectivity shows that no infected individuals were found in the population of An. Funestus. This would probably be due to the small number of mosquitoes tested.

This study shows that the lack of access to controlled meteorological and entomological data across all months of the year and their quality has considerably undermined the quality of the climate and the analysis of some control indicators.

Whether or not observed increases in infectivity and aggressiveness in northern Benin during the last thirty years are associated with co-varying changes in local temperature, possibly connected to global changes in climate, has been debated for decade. Studies, using differing data sets and methodologies, produced conflicting results regarding the occurrence of temperature trends and their likelihood of being responsible, at least in part, for the increases in malaria transmission in Northern Sudan.

A time series of quality controlled daily temperature and rainfall data from northern Benin.

In order to develop a pre-alert system for Benin, not only is it essential to monitor the vulnerability of the population to increased malaria transmission, but it is also important to predict and observe weather conditions. It appears that replacement of natural swamp vegetation with agricultural crops has led to increased climatic parameters, which may be responsible for elevated malaria transmission risk in cultivated areas.

\section{Conclusion}

The objective of this study is to study the influence of climatic parameters on the aggression and infectivity of Anopheles $s l$ in the implementation communes of the strategy of large-scale indoor spraying to fight against malaria in the North. East of Benin. This study showed that climatic factors contributed more to the strong anopheles activity from June to August in the study area. The climate observed in northern Benin has a real impact on Anopheles density and weakens current and future vector control strategies.

The present results provide information on the temporal and geographical influence of the entomological and climatic parameters favorable to the transmission of malaria and will be of great utility for the decision-making regarding the quality of the effectiveness of vector control against malaria. Malaria in North Benin.

\section{Authors' Contributions}

ASS, FA, RA and MCA designed the study. ASS, GGP, FA and MCA participated in the design of the study. ASS, IA, SA, FA and AAS collected entomological data. ASS, SA, FA and AAS carried out bioassays and laboratory analysis. ASS and MCA drafted the manuscript. FA, AS, FD and MCA critically revised the manuscript for intellectual content. All authors read and approved the final manuscript.

\section{Conflict of Interest Statement}

1) All the authors do not have any possible conflicts of interest.

2) The authors declare that they have no competing interests

\section{Acknowledgements}

It is my pleasure to extend my sincere gratitude and appreciation to the collaborators of the Center of Entomological Research of Cotonou, in particular USAID, WHO, and Benin NMCP for their interest in my work and for the development of scientific research in Africa. We are very grateful to the people in our study area who kindly allowed us to have access to their houses to sample mosquitoes, as well as to the numerous volunteers who daily recorded temperature. Eventually, we would like to express our sincere gratitude to Dr. Azondekon Roseric for providing us with linguistic support and other corrections.

\section{References}

[1] Craig MH, Snow RW, Le Sueur D. A climate based distribution model of malaria transmission in sub-Saharan Africa. Parasitol Today. 1999; 15: 105-111.

[2] Hay SI, Snow RW, Rogers DL. Predicting malaria seasons in Kenya using multitemporal meteorological satellite sensor data. Trans R Soc Trop Med Hyg. 1998; 92: 12-20.

[3] Grover-Kopec E, Kawano M, W Klaver RW, Blumenthal B, Ceccato P, Connor SJ. An online operational rainfallmonitoring resource for epidemic malaria early warning systems in Africa. Malar J. 2005; 4: 6. 
[4] Thomson MC, Mason SJ, Phindela T, Connor SJ. Use of rainfall and Sea Surface Temperature monitoring for Malaria Early Warning in Botswana. Am J Trop Med Hyg. 2005; 73: 214-221.

[5] Mouchet J, Manguin S: Global warming and malaria expansion. Annales de la Société Entomologique. 1999, 35: 549-555.

[6] WHO: World Malaria Report 2009. Geneva, Switzerland: World Health Organization; 2009.

[7] Steketee RW, Campbell CC. Impact of national malaria control scale-up programmes in Africa: magnitude and attribution of effects. Malar J 2010; 9: 299.

[8] Morens DM., Folkers GK., and Fauci AS. The challenge of emerging and re-emerging infectious diseases. Nature. 2004; 430: $242-249$.

[9] Jones KE, Patel NG, Levy MA, Storeygard A, Balk D, Gittleman JL, Daszak P. Global trends in emerging infectious diseases. Nature. 2008; 451: 990-993.

[10] Suaya JA, Shepard DS, Siqueira JB, Martelli CT, Lum LC, Tan LH, Kongsin S, Jiamton S, Garrido F, Montoya R et al. Cost of Dengue Cases in Eight Countries in the Americas and Asia: A Prospective Study. American Journal of Tropical Medicine and Hygiene. 2009; 80: 5: 846-855.

[11] Kouame AKD, Adingra YGP, Kassi AJ, Toure OA, Hauhouot AC. Contribution des données géospatiales à l'étude du risque de paludisme en milieu péri-urbain: cas de la localité d'Anonkouakouté (Abidjan, Côte d'Ivoire). International Journal of Engineering Science Invention (IJESI). 2018; 7: 1: $81-88$.

[12] Taylor SE, Lehman BJ, Kiefe CI, Seeman, TE. Relationship of early life stress and psychological functioning to adult Creactive protein in the Coronary Artery Risk Development in Young Adults study. Biological Psychiatry. 2006; 60: 819824 .

[13] Lehmann T, Diabate A. The molecular form of Anopheles gambiae: aphenotipic perspective. Infect Genet Evol. 2008; 8: 737-746.

[14] Charlwood JD, Billingsley PF. Dry season refugia of malariatransmitting mosquitoes in a dry savannah zone of East Africa. Am J Trop Med Hyg. 2000; 62: 726-732.

[15] Donnelly MJ, Simard F, Lehmann T. Evolutionary studies of malaria vectors. Trends Parasitol. 2002; 18: 75-80.

[16] Kweka JE, Zhou G, Munga S, Lee M, Atieli EH, Nyindo M, Githeko KA, Guiyun Yan. Anopheline Larval Habitats Seasonality and Species Distribution: A Prerequisite for Effective Targeted Larval Habitats Control Programmes. journal.pone. 2012; 7: 12.

[17] Kpondjo NM, Développement des larves de moustiques dans un écosystème particulier: milieu sous jacinthe d'eau Eichhorniacrassipes (Mart) Solms-Laubauch, 2008.
[18] AFB. Faune et flore des milieux humides, sante publique, http://www.zones-humides.org/moustiques-zoneshumides.2018.

[19] IRSP, prévention et renforcement des systèmes de santé programmes et resumes des communications benin. 2016; 148.

[20] Ministère de la santé du bénin. 2016.

[21] Annuaire des statistiques sanitaires du Benin. 2016; 164.

[22] Beier JC, Perkins PV, Wirtz RA. Field evaluation of an enzyme-linked immune sorbent assay (ELISA) for Plasmodium falciparum sporozoite detection in anopheline mosquitoes from Kenya. Am J Trop Med Hyg. 1987; 36 (3): 459-468. PubMed Abstract.

[23] Beier JC, Perkins PV, Wirtz RA, Koros J, Diggs D, Gargan TP and Koechy DK. Blood meal identification by direct enzymelinked immunosorbent assay (ELISAl, lested on Anopheles (Diptera: Culicidae) in Kenya. J. Med. Entomol. 1988; 25:9-1.

[24] Molineaux L, Storey J, Cohen JE, Thomas A. A longitudinal study of human malaria in the West African savanna in the absence of control measures: Relationships between different Plasmodium species, in particular P. falciparum and $\mathrm{P}$. malariae. American Journal of Tropical Medicine and Hygiene. 1980; 29:725-737. [PubMed] [Google Scholar]

[25] Klinkenberg E, McCall PJ, Michael DW, Amerasinghe FP, Donnelly MJ. Impact of urban agriculture on malaria vectors in Accra, Ghana. Malaria Journal. 2008; 7: 151. DOI: 10.1186/1475- 2875-7-151.

[26] Akono NP, Tonga C, Mbida J, Ngo HO, Awono-Ambene P, Ndo C, et al. Anopheles gambiae, vecteur majeur du paludisme à Logbessou, zone péri-urbaine de Douala (Cameroun). Bull Soc Pathologie Exotique. 2015; 108: 360 368. DOI: $10.1007 / \mathrm{s} 13149-015-0452-3$.

[27] Rodhain F, Pérez C, 1985. Précis d'entomologie médicale et vétérinaire, Notion d'épidémiologie des maladies à vecteurs. Maloine s. a.; 77-152.

[28] Tchuinkam T. Biologie et épidémiologie de la transmission homme-moustique de Plasmodium falciparum: rôle de la gamétocytémie, influence des antimalariques et implications pour le paludisme d'altitude. Thèse d'Etat, Université de Yaoundé $I .2007$.

[29] https://www.mosquitosquad.com/central-illinois/aboutus/blog/2018/july/how-does-weather-affect-mosquito-activity-

[30] Yadouleton A, Aïkpon R, Houndeton G, Aboubacar S, Ursins F, Tchibçozo C, et al. Preliminary entomological data for the implementation of insecticide residual spray in the district of Copargao, North-East of Benin. 2018; Int. J. Biol. Chem. Sci. 12 (5): 1993-2003. 